\title{
Vitamin $D$ as a modulating agent of metformin and insulin in patients with type 2 diabetes
}

\author{
Fatemeh ABDI 1 (D), Monireh MOVAHEDI 1 * (D), Mir Mohammad ALAVI NIKJE 2 (D), \\ Laleh GHANEI 3 (D), Sako MIRZAIE 4 * (D)
}

1 Department of Cellular and Molecular Biology, Islamic Azad University, Tehran North Branch, Tehran, Iran.

2 Department of Chemistry, Faculty of Science, Imam Khomeini International University, PO box 288.

3 Department of Endocrinology, Tehran Medical Sciences Branch, Islamic Azad University, Tehran, Iran.

4 Department of Biochemistry, Sanandaj Branch, Islamic Azad University, Sanandaj, Iran.

* Corresponding Authors. E-mail: sako.biochem@gmail.com (S.M.); Tel. +98-918-376 -1833; Mon_movahedi@yahoo.com (M.M.)

Received: 11 September 2018/ Revised: 08 November 2018/ Accepted: 11 November 2018

\begin{abstract}
Diabetes, which is one of the most important health challenges for humankind, is associated with impaired glucose metabolism. Diabetes mellitus (DM) includes two major types of diabetes, type 1 (T1DM) and type 2 (T2DM). In this study, in the beginning, interventional and experimental studies were performed on 45 patients with T2DM, and the modulating effects of vitamin D were evaluated on the biochemical parameters of patients with the restricted diet, consuming metformin or insulin. With regard to our experimental results, the combination treatment of metformin/ vitamin $\mathrm{D}$ or insulin/ vitamin D can reduce the fasting blood sugar (FBS). A combination of vitamin D with insulin decreases the insulin resistance and raises the insulin sensitivity in patients with T2DM. The combination treatment of vitamin D and metformin led to a decrease in the level of mRNA of GLUT4, and also it's trafficking from the cytosol to the plasma membrane. At the second phase of the present study, molecular dynamics (MD), molecular docking, MM/PBSA, and $\mathrm{QM} / \mathrm{MM}$ were occupied to examine the structural behavior of VDR, in the free or ligand bound state, during $50 \mathrm{~ns}$. The MD results exhibited that in the presence of metformin, the flexibility of residues comprising helix 12 from vitamin D-bound VDR was decreased. In addition, metformin decreased the radius of gyration of agonist-bound VDR. In addition, QM/MM results showed that metformin diminished the binding free energy between VDR and vitamin D. Our computational data demonstrated that metformin, in the presence of vitamin D, reinforces the interaction between VDR and its co-activator protein.
\end{abstract}

KEYWORDS: Diabetes mellitus type 2; metformin; vitamin D; molecular dynamics; vitamin D receptor; QM/MM.

\section{INTRODUCTION}

One of the most important and well-known chronic metabolic disorders in human is DM. It has been classified into two types; T1DM or insulin-dependent diabetes mellitus, which is correlated with the destruction of $\beta$-cells of the pancreatic tissue and is characterized with insufficient secretion of insulin, and T2DM that is identified with the resistance to the secreted insulin. T2DM is responsible for $90 \%$ of the overall prevalence of diabetes [1]. This proportion is up to $8.3 \%$ of the adult population with equal percentages in women and men [2] and is coming with the clinical symptoms like hyperglycemia and hypercholesterolemia [1, 3]. T2DM also increases the risk of cardiovascular diseases involving renal failure, atherosclerosis, ophthalmia, and neurotoxicity $[1,4]$. Other clinical consequences include acanthosis, nigricans, sexual dysfunction, and frequent infections. In the uncontrolled and severe T2DM, coma and death also can be occurred among the patients. Just in 2013, 382 million people were diagnosed with DM [5]. It has been predicted that the population with diabetes rise to 592 million by 2035. Typically, T2DM is controlled by regular exercise and relevant diet. If the blood sugar levels are not adequately decreased by the corrected lifestyle, medications will be the obligatory items. Due to the restricted effectiveness and undesirable side effects of current medications, unfortunately, anti-

How to cite this article: Abdi F, Movahedi M, Alavi Nikje MM, Ghanei L, Mirzaie S. Vitamin D as a modulating agent of metformin and insulin in patients with type 2 diabetes. J Res Pharm. 2019; 23 (3): 360-378. 
diabetic drugs and pharmaceutical treatments are considerably far away from being satisfactory in the treatment of T2DM [1]. With regard to this fact, T2DM still is an untreatable sickness with a high death rate and high poor life quality [1,6]. So, the developments of new potent and effective medications and treatments are highly demanded. It is also critical that new treatments have the lowest side effects and toxicity. Metformin belongs to the biguanide family and is prescribed as the first choice for the treatment of T2DM. This drug is prescribed to at least 120 million people worldwide and has an effective and reasonable anti-hyperglycemic property without causing overt hypoglycemia. Metformin effects on tyrosine kinase activity of insulin plasma membrane receptors and decreases the resistance of cells to the insulin [7]. Along with this, metformin sharply increases the plasma levels of glucagon-like peptide-1 [8] and decreases hepatic glucose production [9], mainly by inhibiting gluconeogenesis [10, 11]. Glucose, as a major source of energy in the body of mammalian cells, is transferred across the plasma membrane by facilitated diffusion by glucose transporters or GLUT. Up to now, 14 isoforms of GLUT have been identified in human cells; GLUT1-GLUT12, GLUT14, and HMIT [12]. These receptors are unique in the view of substrate specificities, kinetic properties, and tissue expression profiles. GLUT4 includes special sequences in its amine and carboxyl terminus that causes membrane trafficking capability [13]. This transporter is translocated from cytosol to the plasma membrane in answer to insulin and other stimuli [13, 14]. Studies showed that GLUT4 is not expressed in the lymphocytes of healthy people. Based on prior studies, vitamin D is a critical substance in the human body and its low level in the blood is attributed to insulin resistance and diabetes. Mattila et al. clarified the relation between vitamin D and T2DM [15], and then, Palomer et al. expressed the vitamin D role in glucose tolerance due to its influence on insulin sensitivity [16]. It has been shown that vitamin D can up-regulate the insulin receptor gene and finally decrease the insulin resistance [17]. Vitamin D applies these impacts via a ligand-activated transcription factor, vitamin D receptor (VDR) [18]. In spite of the importance of the vitamin D role in the glucose metabolism and homeostasis, just a few studies investigate the possible properties of its combination with other anti-diabetic drugs on human factors with T2DM. Also, the mechanism of such effects is completely unknown. So this study was programmed and conducted into two phases. In the first phase, the modulating effects of vitamin D on T2DM patients who treated with metformin or insulin were evaluated experimentally. In the second phase, for the first time, by employing the computational biology and molecular modeling methods, the interaction of vitamin D with the VDR in the presence or absence of metformin was investigated.

\section{RESULTS and DISCUSSION}

\subsection{Experimental biochemical analysis}

This study was conducted in two independent phases. In the first phase, 45 patients with T2DM were selected for an interventional experiment. The effects of vitamin D3 were evaluated on the biochemical parameters of three groups: patients with a controlled diet, patients with metformin treatments and finally, patients with insulin treatments. In the second phase, molecular docking and dynamics were employed to study the VDR, vitamin D3 and metformin, computationally. Based on our experimental data, vitamin D3 administration has not any significant effect on the FBS level of group I $(\mathrm{P}<0.05)$. On the contrary, in group II and III, vitamin D3 led to a significant decrease in the FBS of patients $(\mathrm{P}<0.05)$. Vitamin D can affect on glucose metabolism and its level by two major mechanisms including direct and indirect effects. The first direct effect is that this vitamin could stimulate the insulin release by increasing the expression of VDR and 1-alpha hydroxylase in the pancreatic $\beta$-cells [19]. The second direct mechanism is related to the binding of $1,25(\mathrm{OH}) 2 \mathrm{D}-$ VDR complex to the vitamin D response element of the insulin receptor gene at the tissue [20, 21]. So, the expression of the insulin receptor is increased and the insulin responsiveness for glucose transport is elevated. In the third direct mechanism, it is believed that vitamin D could suppress the release of some inflammatory cytokines [22]. Based on data shown in Table 1, after vitamin D3 treatment, the level of insulin in group I and II has remained unchanged. So, the reduction of FBS in group II is independent of insulin secretion. The concentration of serum calcium in group II is increased from 9.5 to $9.9 \mathrm{mg} / \mathrm{dl}(\mathrm{P}<0.05)$. It has been demonstrated that vitamin $\mathrm{D}$ engages an indirect role by its effect on the extracellular and intracellular calcium regulation which is crucial for the intervention of glucose transport in the target tissues [22, 23]. Anyway, the combination treatment of insulin and vitamin D in group III stimulates the insulin secretion in pancreatic $\beta$-cells (Table 1 ). 
Table 1. Biochemical parameters measurements among three studied groups before and after treatment with vitamin D3.

\begin{tabular}{|c|c|c|c|c|c|c|c|c|c|}
\hline & \multicolumn{2}{|c|}{ Group I } & \multirow{2}{*}{$\mathrm{p}$-value } & \multicolumn{2}{|c|}{ Group II } & \multirow{2}{*}{$\mathrm{p}$-value } & \multicolumn{2}{|c|}{ Group III } & \multirow{2}{*}{$\mathrm{p}$-value } \\
\hline & before & after & & before & after & & before & after & \\
\hline $\begin{array}{l}\text { Triglyceride } \\
(\mathrm{mg} / \mathrm{dL})\end{array}$ & $174.8 \pm 36.2$ & $164.6 \pm 29.1$ & 0.276 & $199.6 \pm 42.6$ & $165.5 \pm 25.3$ & $0.005^{*}$ & $169.8 \pm 39.9$ & $139.1 \pm 52.2$ & $0.001^{*}$ \\
\hline $\begin{array}{l}\text { Potassium } \\
(\mu \mathrm{mol} / \mathrm{L})\end{array}$ & $4.3 \pm 0.49$ & $4.1 \pm 0.42$ & 0.122 & $4.2 \pm 0.39$ & $4.1 \pm 0.32$ & 0.199 & $4.08 \pm 0.33$ & $4.1 \pm 0.23$ & 0.195 \\
\hline $\begin{array}{l}\text { Sodium } \\
(\mu \mathrm{mol} / \mathrm{L})\end{array}$ & $140.2 \pm 2.9$ & $140.4 \pm 1.68$ & 0.67 & $138.8 \pm 2.9$ & $139.4 \pm 2.5$ & 0.209 & $139.1 \pm 2.8$ & $139.3 \pm 2.28$ & 0.589 \\
\hline $\begin{array}{l}\text { HDL } \\
(\mathrm{mg} / \mathrm{dL})\end{array}$ & $39.2 \pm 4.3$ & $39.9 \pm 3.9$ & 0.159 & $41.4 \pm 4.01$ & $41.9 \pm 2.9$ & 0.377 & $39.2 \pm 2.9$ & $40.4 \pm 3.5$ & $0.018^{*}$ \\
\hline $\begin{array}{l}\text { LDL } \\
(\mathrm{mg} / \mathrm{dL})\end{array}$ & $100.8 \pm 11.5$ & $96.7 \pm 9.6$ & $0.016^{*}$ & $96.1 \pm 13.7$ & $89.3 \pm 9.3$ & $0.002^{*}$ & $100.3 \pm 15.4$ & $92.5 \pm 10.7$ & $0.003^{*}$ \\
\hline $\begin{array}{l}\text { Cholesterol } \\
(\mathrm{mg} / \mathrm{dl})\end{array}$ & $185.6 \pm 29.7$ & $171.5 \pm 22.4$ & $0.01^{*}$ & $190.3 \pm 24.3$ & $174.8 \pm 16.3$ & $0.011^{*}$ & $207.5 \pm 21.1$ & $184.6 \pm 18.5$ & $0.002^{*}$ \\
\hline $\begin{array}{l}\text { Calcium } \\
(\mathrm{mg} / \mathrm{dL})\end{array}$ & $9.9 \pm 0.61$ & $10.1 \pm 0.62$ & 0.213 & $9.5 \pm 0.61$ & $9.9 \pm 0.36$ & $0.02^{*}$ & $9.3 \pm 0.54$ & $9.8 \pm 0.51$ & $0.002^{*}$ \\
\hline $\begin{array}{l}\text { Phosphorus } \\
\text { (mg/dL) }\end{array}$ & $3.9 \pm 0.27$ & $4.06 \pm 0.15$ & $0.015^{*}$ & $4.03 \pm 0.38$ & $4.14 \pm 0.25$ & 0.112 & $3.8 \pm 0.31$ & $4.03 \pm 0.31$ & $0.011^{*}$ \\
\hline $\begin{array}{l}\text { Insulin } \\
(\mu \mathrm{U} / \mathrm{mL})\end{array}$ & $0.39 \pm 0.046$ & $0.31 \pm 0.037$ & 0.09 & $0.28 \pm 0.027$ & $0.29 \pm 0.023$ & 0.135 & $0.42 \pm 0.034$ & $0.44 \pm 0.038$ & $0.001^{*}$ \\
\hline $\begin{array}{l}\text { FBS } \\
(\mathrm{mg} / \mathrm{dL})\end{array}$ & $102.4 \pm 16.9$ & $108.2 \pm 11.03$ & 0.08 & $125.3 \pm 24.2$ & $115.3 \pm 19.8$ & $0.01 *$ & $179.06 \pm 37.4$ & $153.8 \pm 29.1$ & $0.002^{*}$ \\
\hline $\begin{array}{l}\text { Magnesium } \\
(\mathrm{mg} / \mathrm{dL})\end{array}$ & $2.24 \pm 0.37$ & $2.3 \pm 0.29$ & 0.384 & $2.05 \pm 0.36$ & $2.16 \pm 0.29$ & 0.171 & $1.9 \pm 0.28$ & $2.01 \pm 0.18$ & 0.068 \\
\hline HOMA-IR & $1.8 \pm 0.79$ & $1.5 \pm 0.41$ & 0.068 & $1.6 \pm 0.66$ & $1.5 \pm 0.46$ & 0.637 & $3.39 \pm 1.3$ & $3.01 \pm 1.11$ & $0.046^{*}$ \\
\hline QUICKI & $0.62 \pm 0.015$ & $0.66 \pm 0.015$ & 0.239 & $0.65 \pm 0.16$ & $0.66 \pm 0.014$ & 0.132 & $0.53 \pm 0.008$ & $0.55 \pm 0.014$ & $0.021^{*}$ \\
\hline $\begin{array}{l}\text { Vitamin D3 } \\
(\mathrm{ng} / \mathrm{mL})\end{array}$ & $26.5 \pm 9.4$ & $51 \pm 16.6$ & $0.000^{*}$ & $21.6 \pm 6.8$ & $37.4 \pm 7.8$ & $0.000^{*}$ & $21.9 \pm 8.3$ & $33.6 \pm 7.4$ & $0.000^{*}$ \\
\hline
\end{tabular}

Comparison between before and after treatment using "paired $\mathrm{t}$ - test".

* Significant.

Since vitamin D increases the phosphorus absorption from the intestine [24], the concentration of phosphorous in group I and III is increased. This elevation was not statistically significant in group II. Upon Table 1, LDL and cholesterol concentrations of all groups were decreased. Theoretically, vitamin D could affect of lipid profile via direct and indirect mechanisms [25]. The Indirect mechanism comprises of the influence of vitamin D on PTH and/or on the calcium balance [25]. In the direct mechanism, it seems that vitamin D block adipocyte differentiation [26, 27]. Prior studies showed that VDR null mice have lower TG than wild-type. To justify this matter, it has been recommended that vitamin D affects adipogenesis in a dose-dependent manner. In the low dose, it has a stimulating effect, whereas in the high dose, it shows an inhibiting effect on adipogenesis. Based on our results, vitamin D has no effect on TG profile when it treated alone. Some scientists strongly believe that raising the serum vitamin $\mathrm{D}$ levels to at least $80 \mathrm{nmol} / \mathrm{L}$ would be beneficial effects on lipid profile and health [25]. However, a decrease in TG was appeared in group II and III (Table 1). HOMA-IR, a biomarker of insulin resistance quantification, exhibited a meaningful $(\mathrm{P}<0.05)$ reduction in group III (Table 1). Our results were not in correspondence with the similar experiment done in diabetic rats [1]. Amin et al. showed that the combination treatment of vitamin D and metformin, in comparison with control, decreases the HOMA-IR in diabetic rats [1]. After the increase in the glucose level of plasma by exogenous glucose, its level is rapidly decreased to the normal level. The main mechanism of such reduction is related to insulin-stimulated glucose transporter (GLUT). One of the most important GLUT is named GLUT4 and is a critical mediator of glucose elimination from the circulation and a key regulator of whole-body glucose homeostasis. This transporter belongs to the family of sugar transporter proteins having 12-transmembrane domains [13]. Figure 1 illustrates the content of GLUT4 on the surface of peripheral lymphocytes. Figure 2 exhibits the expression level of GLUT4 in these cells. As can be seen in these figures, the content of GLUT4 has remained unchanged in group I and III $(P>0.05)$. The emerging of GLUT4 in the plasma membrane of lymphocytes in group II was significantly decreased. The presence of GLUT4 in different organs of the body has diverse physiological effects. It has been shown that transgenic mice expressing high levels of GLUT4 in adipose tissue [28, 29] or in skeletal muscle [30] 
are severely insulin sensitive and glucose tolerant [13]. In a converse manner, the lack of sufficient expression of GLUT4 in either adipose tissue or skeletal muscle of the animal model brings insulin resistance and an approximately equivalent incidence of diabetic animals [31, 32]. However, GLUT4 has not been found and expressed in circulating lymphocytes of healthy people or patients with T1DM [12]. The glucose indirectly increases the level of GLUT4 in lymphocytes; the elevated level of glucose in the blood causes the release of insulin from the pancreatic $\beta$-cell. Insulin stimulates the trafficking of GLUT4 from the cytosol to the surface of plasma membrane. Based on Figure 1 and 2, the combination treatment of patients with vitamin D and metformin decreases the expression level and trafficking of GLUT4 on the circulating lymphocytes. The reduction in the GLUT4 level in blood cells is directly associated with the healthy condition.

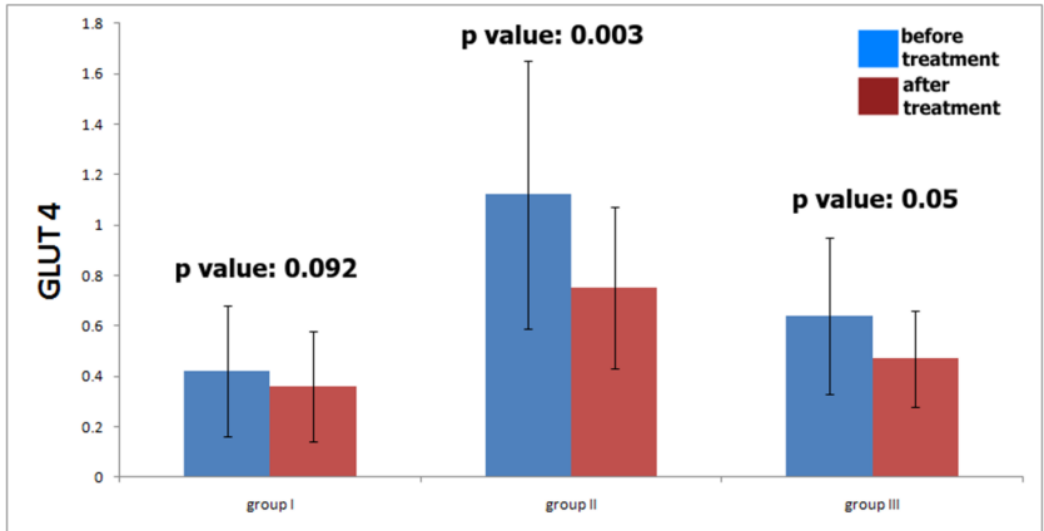

Figure 1. The content of GLUT4 on the surface of peripheral lymphocytes in patients with T2DM. Comparison between before and after treatment was made using "paired $\mathrm{t}$ - test".

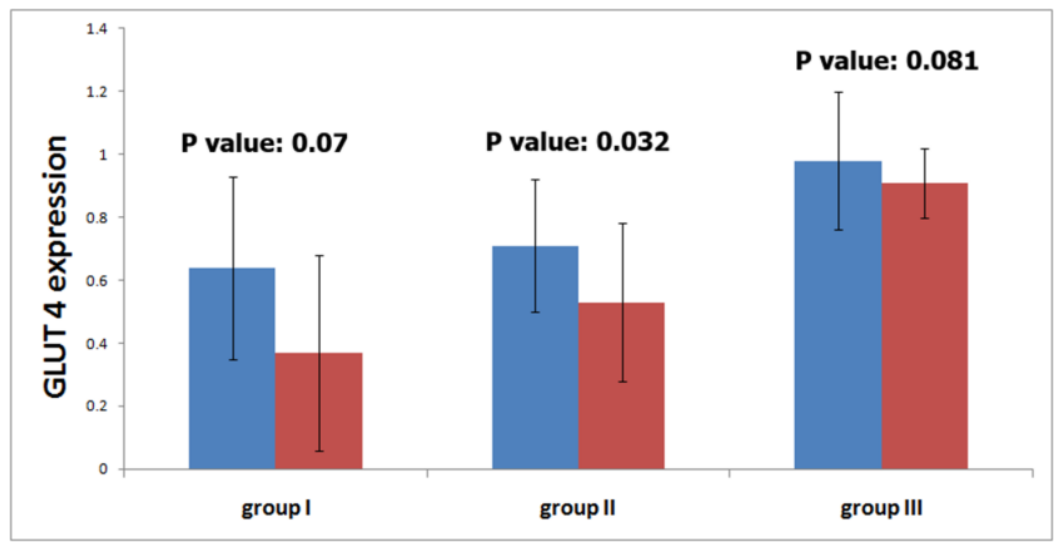

Figure 2. The expression level of GLUT4 in the peripheral lymphocytes in patients with T2DM. Comparison between before and after treatment was made using "paired $\mathrm{t}$ - test".

\subsection{MD simulation on VDR in free and ligand bound state}

With the rises of the power of computers, MD simulations of proteins were developed in the early 1980's and after that, widely employed to study the motions of proteins and other biopolymers. MD studies with the wide and different approximations have been especially successful in studying the protein folding problem and the influence of protein motions on catalysis and ligand binding [33]. In the current study, three independent MD simulations were introduced for free VDR, VDR: vitamin D and VDR: vitamin D: metformin complexes. After completion of the MD study, for each run, the root mean square deviation (RMSD) of the protein backbone was computed to check and measurement of protein and simulation stability (Figure 3). 


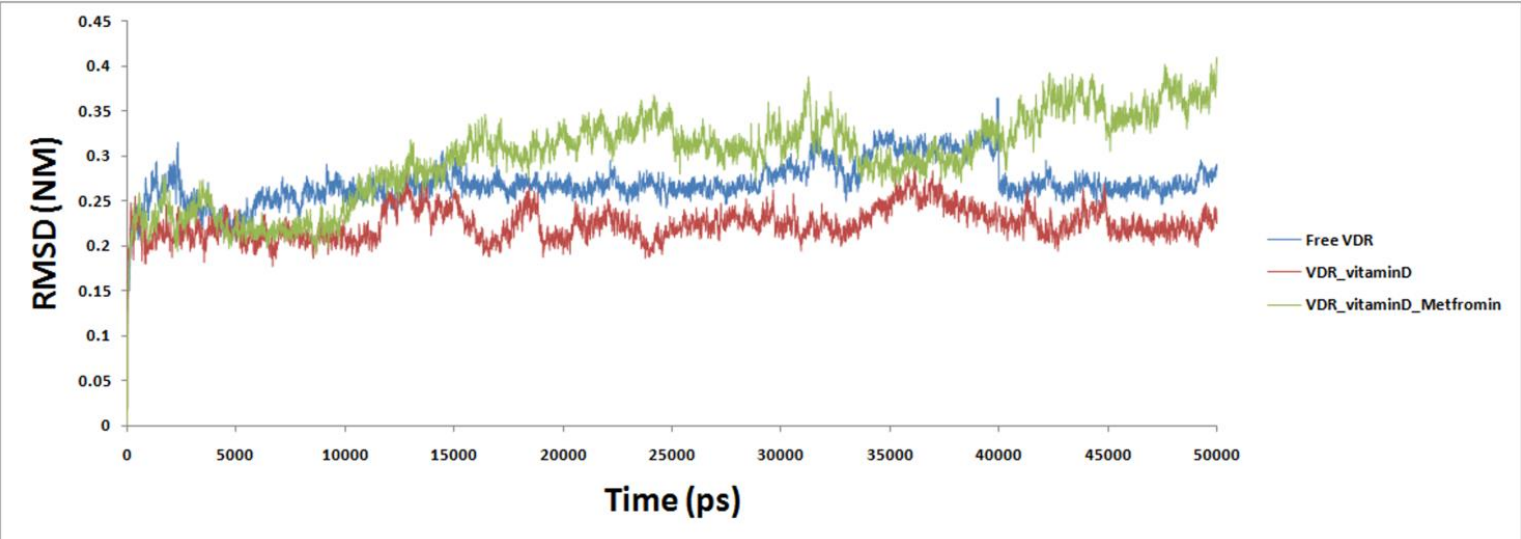

Figure 3. Temporal RMSD values of free VDR (blue line), VDR: vitamin D (red line) and VDR: vitamin D: metformin (green line).

With the RMSD analyzes, it could be found that how much the protein has changed or how much the protein conformations vary during the course of the simulation quantitatively. For free VDR, the RMSD is $2.5 \AA$ at 10000 ps. After that, it increased up to $3.6 \AA$ at 39910 . Then it decreases to $2.6 \AA$ and the system reaches equilibrium. In VDR: vitamin D complex, the system shows a lower RMSD value than the free VDR and VDR: vitamin D: metformin systems. The average temporal RMSD of VDR: vitamin D complex is $2.2 \AA$. In the system containing VDR, vitamin D, and metformin, the average RMSD is $2.9 \AA$. The higher RMSD of this system is associated with a lower rigidity of protein (Figure 3). To analyze the residue flexibility during 50000 ps MD simulation, the root mean square fluctuation (RMSF) values of three systems were calculated and depicted in Figure 4.

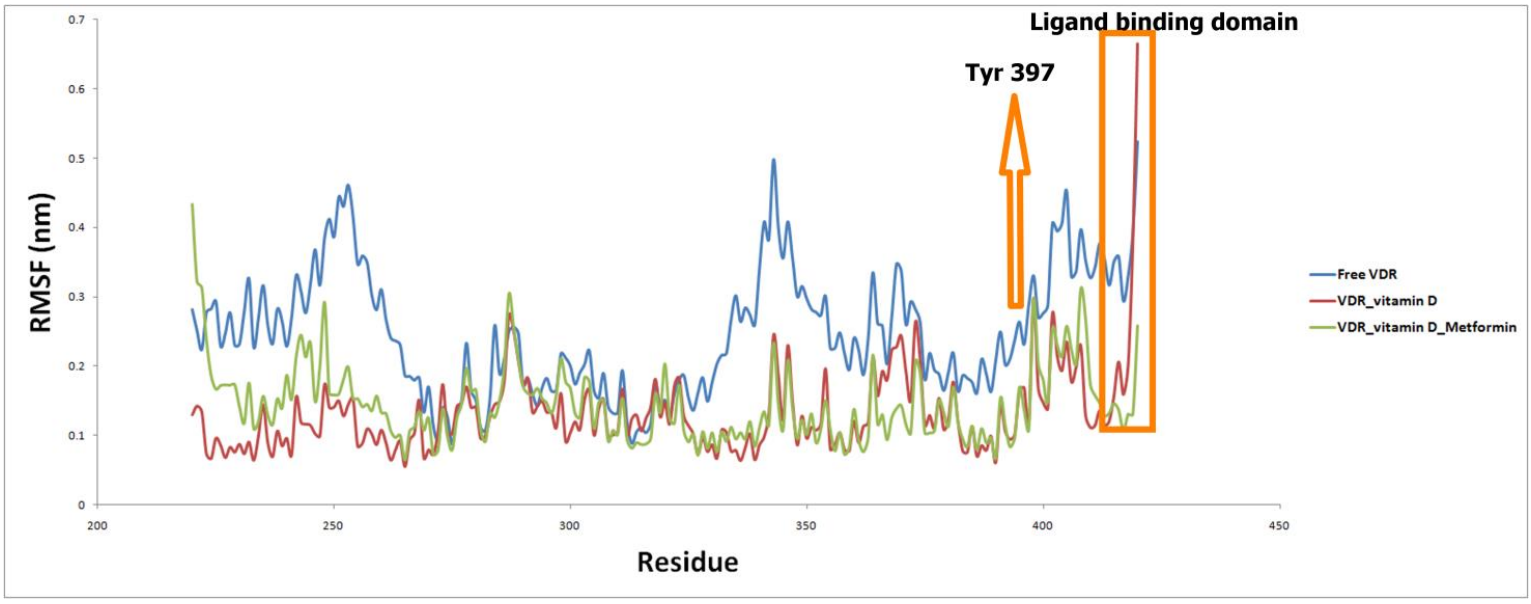

Figure 4. Temporal RMSF values of free VDR (blue line), VDR: vitamin D (red line) and VDR: vitamin D: metformin (green line).

Residues 413-419 construct the helix 12 in the VDR. This helix is located in the carboxy terminus of VDR and forms a ligand binding domain (LBD). It includes a crucial ligand-modulated interface for the interaction with co-activator proteins [34]. Upon data depicted in Figure 4, in the free VDR, the RMSF values of Leu 415 and Glu 416 are 3.51 and $3.58 \AA$, respectively. In the VDR: vitamin D and VDR: vitamin D: metformin complexes, the RMSD value of Leu 415 is 1.5 and $1.4 \AA$, respectively. There was the same situation for Glu 416. The RMSF value of Glu 416 was smaller in both substrates bound VDRs ( $2 \AA$ for vitamin D-bound VDR and $1.3 \AA$ for vitamin $\mathrm{D} /$ metformin-bound VDR). Alanine scanning and mutation based studies showed that mutation of amino acid residues Leu 415, Glu 416 and Phe 418 completely abolished activity of the VDR [35, 36]. Our data 
showed that upon agonist binding (vitamin D in our study), the RMSF values of residues Leu 415, Glu 416 and Phe 418 were decreased. In the presence of metformin, the RMSF values of mentioned residues in vitamin D bound VDR were lower than two other systems (Figure 4). For the ligand binding into VDR, the suggested model is called the "folding-door model" [37]. In this model, and upon agonist binding, the folding-door allows ligands easier access to the LBD and easier construction of the active conformation of helix 12 and activation function 2 surface (AF-2). In the presence of VDR agonist, through the folding back of helix 12, AF-2 is formed and subsequently, the agonist-bound VDR is activated [37]. Based on a folding-door model, and after the entrance of agonist, the helix 11 approaches to helix 12 through interaction between Gly 419 and Tyr 397 [37]. The RMSF of Gly 419 in free VDR, VDR: vitamin D, VDR: vitamin D: metformin complexes are 3.9, 3.7 and $1.3 \AA$, respectively (Figure 4). In the free VDR, the RMSF value of Tyr 397 is $2.8 \AA$, whereas for VDR: vitamin D, VDR: vitamin D: metformin complex, this value is 1.1 and $1 \AA$, respectively. The decrease of RMSF values of Gly 419 and Tyr 397 in the presence of metformin can be interpreting with the interacting and approaching these two amino acids. Figure 5A illustrates that the distance between Gly 419 and Tyr 397 in the VDR: vitamin D complex is $4.9 \AA$. In the presence of metformin, this distance was reduced to $3.2 \AA$ (Figure 5B). As mentioned previously, in the active form of VDR, the helix 12 is interacts with co-activator protein.
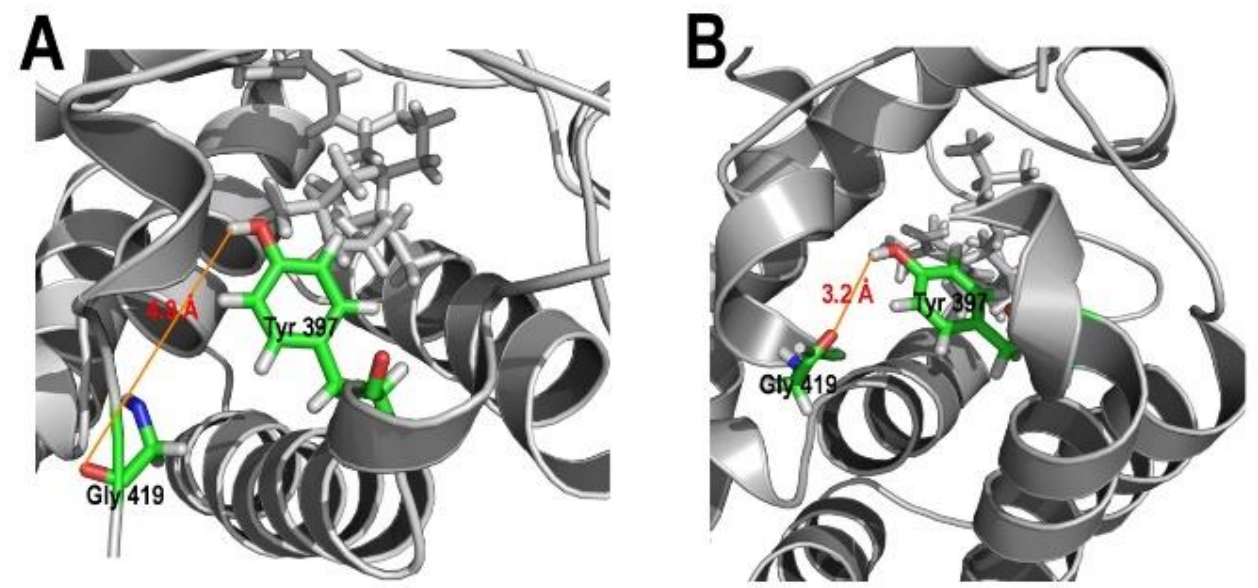

Figure 5. The computed distance between Gly 419 and Tyr 397 in the VDR: vitamin D (Figure 5A) and VDR: vitamin D: metformin complexes (Figure 5B).

The temporal RMSF profile of the co-activator protein is depicted in Figure 6. In comparison with free VDR, the RMSF values of amino acid residues of the co-activator in the presence of vitamin $\mathrm{D} / \mathrm{metformin}$ have been decreased (Figure 6). To understand the level of compaction in the structure of VDR, in the absence and presence of ligand, the radius of gyration $\left(\mathrm{R}_{\mathrm{g}}\right)$ is calculated (Figure 7). Since this parameter is explained as the mass-weighted root mean square distance of a collection of atoms from their common center of mass [37], this analysis illustrates the dimension of protein. The average $R_{g}$ of free VDR is $18.6 \AA$. However, the presences of vitamin D/metformin in the system, caused a decrease in the $\mathrm{R}_{\mathrm{g}}$ of VDR (to $18.2 \AA$ ) (Figure 7). The increase in the protein compactness, in the presence of agonist could be associated with re-orientation of helix 11 and 12 , and subsequently interaction of helix 12 with co-activator protein. Figure 8 shows the orientation of helix 12 and co-activator protein in the absence and presence of metformin in VDR: vitamin D complex. As can be concluded, in the presence of metformin, helix 12 approaches to the co-activator protein. Our data confirm the folding-door model upon agonist binding. The interaction mode between metformin and vitamin D bound VDR is demonstrated in Figure 9. With regard to this figure, one of the metformin molecules is located in the vicinity of Glu 349 and Ala 350 from VDR. It also interacts with the carboxyl side chain of Asp 353 via two hydrogen bonds. 


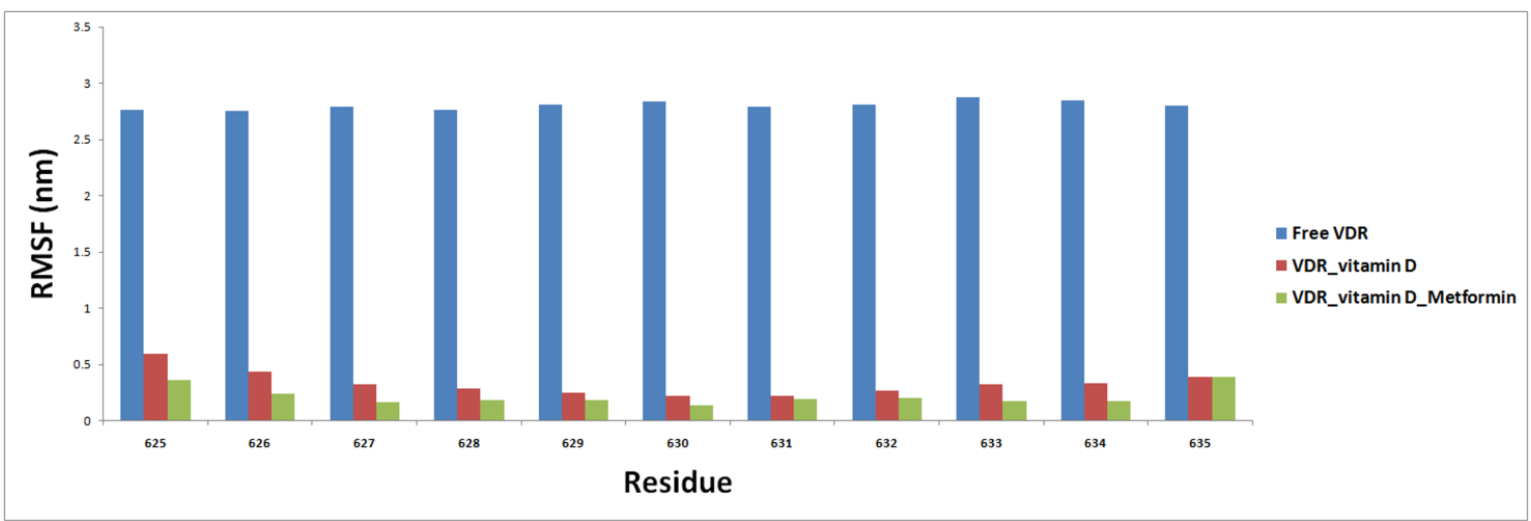

Figure 6. Temporal RMSF profile of co-activator protein in free VDR (blue line), VDR: vitamin D (red line) and VDR: vitamin D: metformin (green line).

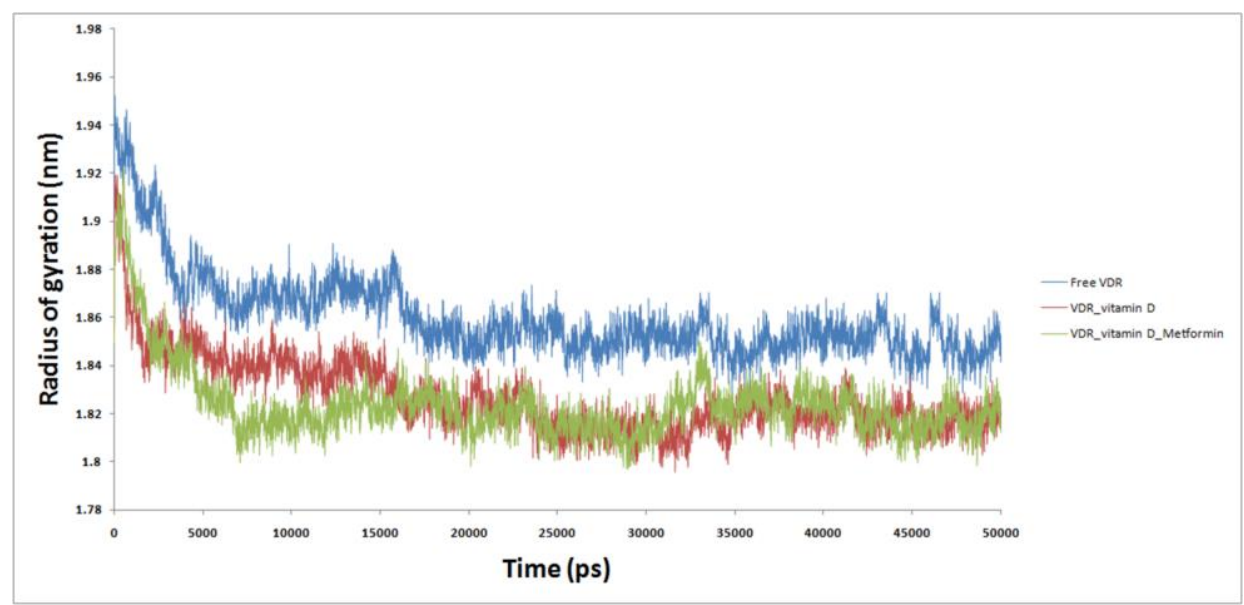

Figure 7. The computed profile of radius of gyration in free VDR (blue line), VDR: vitamin D (red line) and VDR: vitamin D: metformin (green line) during $50 \mathrm{~ns}$ MD simulation.

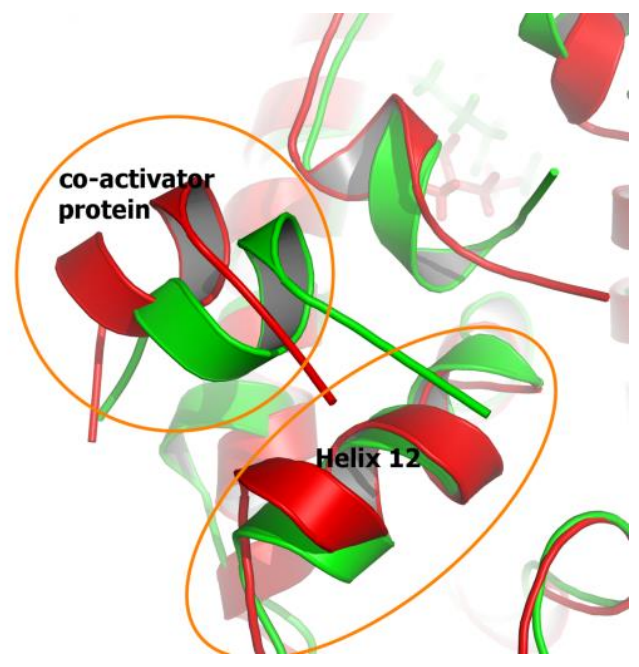

Figure 8. The computed orientation of helix 12 and co-activator protein in the absence (red cartoon presentation) and presence of metformin (green cartoon presentation) in VDR: vitamin D complex. 


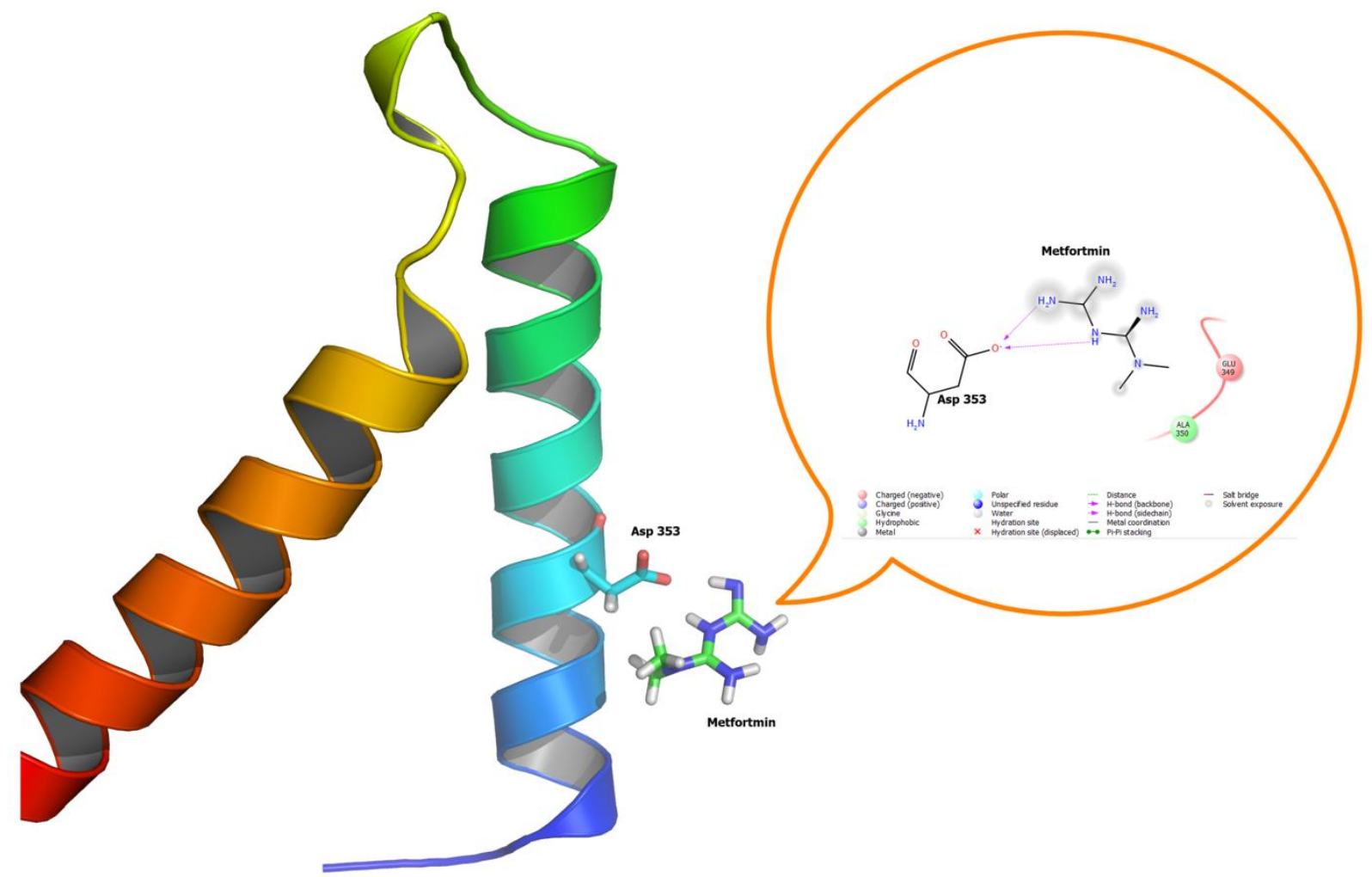

Figure 9. The computed interaction mode between metformin and vitamin D bound VDR.

\subsection{Computation of free energy of binding}

For estimation of free binding energy between vitamin D and VDR, the MM/PBSA method was operated. In comparison with the binding energy derived from the molecular docking packages, this method gives us reliable binding energy values. This type of calculation was applied on the snapshots which extracted from the last $10 \mathrm{~ns}$ of MD trajectories [38]. The binding free energies $\left(\Delta G_{b i n d}\right)$ between VDR and vitamin D in the absence and presence of metformin are -203.4 and $-206 \mathrm{~kJ} \mathrm{~mol}^{-1}$, respectively (Table 2). Our results exhibited that vitamin $\mathrm{D}$ in both states has approximately same salvation energy and solvent-accessible surface area energy. In the presence of metformin, the van der Waals energy between VDR and vitamin D is slightly reduced. However, our data detected that the presence of metformin slightly affects the affinity of VDR to vitamin D.

Table 2. Molecular energy terms calculated between VDR and vitamin D in the absence and presence of metformin.

\begin{tabular}{ccc}
\hline Energy $(\mathrm{kJ} / \mathrm{mol})$ & In the absence of metformin & In the presence of metformin \\
\hline$\Delta \mathrm{E}_{\mathrm{vdw}}$ & $-239.601 \pm 9.352$ & $-252.141 \pm 6.809$ \\
$\Delta \mathrm{E}_{\text {elect }}$ & $-24.378 \pm 2.471$ & $-17.634 \pm 2.440$ \\
$\Delta \mathrm{E}_{\text {solv }}$ & $85.692 \pm 2.783$ & $88.035 \pm 6.108$ \\
$\Delta \mathrm{E}_{\mathrm{SASA}}$ & $-25.126 \pm 0.555$ & $-24.262 \pm 0.543$ \\
$\Delta \mathrm{G}_{\text {binding }}$ & $-203.413 \pm 12.035$ & $-206.002 \pm 10.021$ \\
\hline
\end{tabular}




\section{4. $Q M / M M$ Computations on vitamin $D$ in free and VDR bound states}

Following the MD simulations, the last frame of the vitamin D-bound VDR was introduced to the $\mathrm{QM} / \mathrm{MM}$ calculation. Also, the free form of vitamin D was conducted for DFT calculations. Electronic molecular features like electron density, frontier molecular orbital density fields, such as LUMO, HOMO, and molecular electrostatic map, have been shown to be profitable in QSAR studies to explain biological activity and molecular properties [39, 40]. HOMO/LUMO is very important for charge transfer in the chemical reactions. Molecules with higher HOMO levels tend to be good nucleophiles. On the contrary, the molecules with low LUMO energies tend to be good electrophiles [41]. In the free state of vitamin D, the energy gap is $0.175 \mathrm{eV}$ (Table 3).

Table 3. HOMO, LUMO, energy gap and binding energies $(\mathrm{kcal} / \mathrm{mol})$ of vitamin $\mathrm{D}$ in the binding site of VDR in the absence and presence of metformin.

\begin{tabular}{|c|c|c|c|c|c|c|c|c|c|c|}
\hline \multirow{2}{*}{$\begin{array}{c}\text { Molecule } \\
\text { ID }\end{array}$} & \multicolumn{4}{|c|}{ Vitamin D in free state } & \multicolumn{6}{|c|}{ Vitamin D in VDR bound state } \\
\hline & HOMO & LUMO & $\begin{array}{c}\text { Energy } \\
\text { gap }\end{array}$ & Eligand & HOMO & LUMO & $\begin{array}{l}\text { Energy } \\
\text { gap }\end{array}$ & Ecomplex & Ereceptor & $\begin{array}{c}\text { Binding } \\
\text { energy }\end{array}$ \\
\hline $\begin{array}{l}\text { Vitamin D in } \\
\text { free state }\end{array}$ & -0.20196 & -0.02698 & 0.175 & -709483.68 & - & - & - & - & - & - \\
\hline $\begin{array}{l}\text { Vitamin D in } \\
\text { the absence } \\
\text { of metformin }\end{array}$ & - & - & - & - & -0.13655 & 0.03289 & 0.170 & -721568.1 & -12108.9 & 24.39 \\
\hline $\begin{array}{l}\text { Vitamin D in } \\
\text { the presence } \\
\text { of metformin }\end{array}$ & - & - & - & - & -0.19149 & -0.02913 & 0.162 & -721823.9 & -12315 & -25.24 \\
\hline
\end{tabular}

The smaller energy gap between the HOMO and their corresponding LUMO indicates the chemical reactivity of the molecule [40]. With regard to Table 3, after binding vitamin D to the VDR binding site in the absence of metformin, its energy gap was decreased to $0.170 \mathrm{eV}$. In the presence of metformin, the energy gap was decreased to 0.162 . So, in the presence of metformin, the reactivity of vitamin D in the binding site of VDR is increased. Based on a prior QM/MM study conducted on some VDR agonists, compounds with lower HOMO and LUMO had the higher affinities to bond to VDR [42]. Upon data shown in Table 3, in the presence of metformin, the HOMO of vitamin D was lower than the HOMO of vitamin D in the absence of metformin. Furthermore, it has been demonstrated that the lower QM/MM energy is proportional with the higher VDR agonist activity. The QM/MM energy of vitamin D in the bound state, and in the presence and absence of metformin is -721823.9 and $-721568.1 \mathrm{kcal} / \mathrm{mol}$, respectively. The free binding energy of vitamin $\mathrm{D}$ in the absence of metformin is $24.39 \mathrm{kcal} / \mathrm{mol}$, whereas, in the presence of metformin, this energy is $-25.24 \mathrm{kcal} / \mathrm{mol}$. Thus, the vitamin D: VDR complex in the presence of metformin is more stable than the vitamin D: VDR system that lacks metformin (Table 3). The frontier orbitals of vitamin D in free and bound states, in the absence and presence of metformin, are depicted in Figure 10A and 10B. In these Figures, the positive electron density is shown in red color and negative electron density is presented in blue. The HOMO and LUMO are concentrated on the 1,3-butadiene and 4-methylenecyclohexanol moieties of vitamin D. In the presence of metformin, HOMO of ethylene group of vitamin D has higher size (Figure 10A) and shows a lower intensity in the computed vibrational spectrum (Figure 11). The intensity of the vibrational spectrum of ethylene moiety of vitamin $\mathrm{D}$ in the presence and absence of metformin is 12.67 and 20.75, respectively (frequency of $3249 \mathrm{~cm}^{-1}$ ) (Figure 11). Based on Figure 11, in the system containing VDR and vitamin D, the vibrational intensity of the hydroxyl group from vitamin $\mathrm{D}$ was 68.33. However, in the presence of metformin, the mentioned intensity was 2.25 (in the frequency of $571 \mathrm{~cm}^{-1}$ ). 

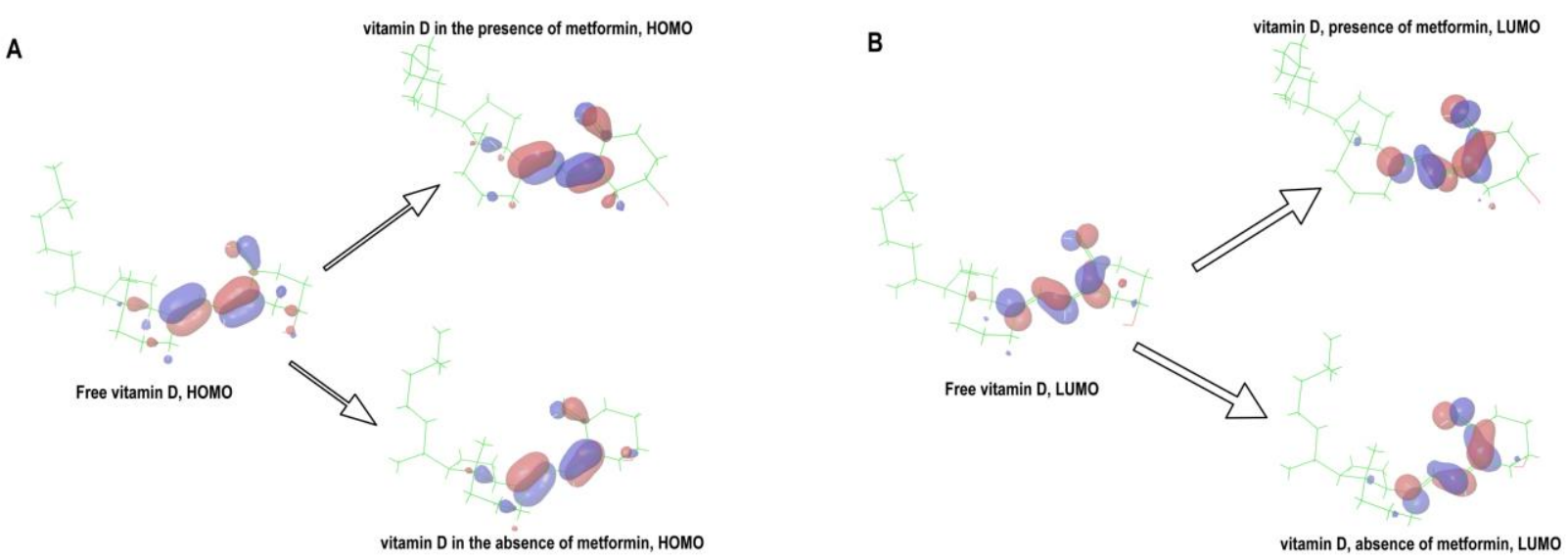

Figure 10. Plots of highest occupied molecular orbital (HOMO) and lowest unoccupied molecular orbital (LUMO) of vitamin D after QMMM studies: HOMO of vitamin D in free and bound states, in the presence and absence of metformin (A). LUMO of vitamin D in free and bound states, in the presence and absence of metformin (B).

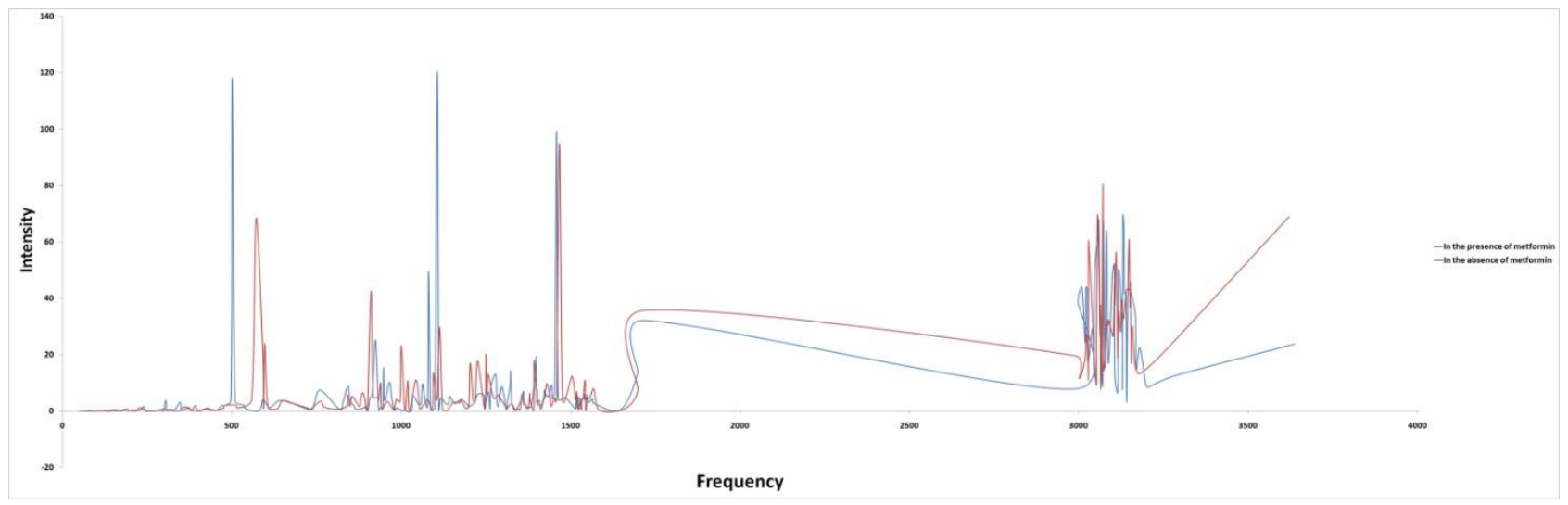

Figure 11. Calculated vibrational spectrum of vitamin $\mathrm{D}$ in the bound state, in the presence and absence of metformin.

\section{CONCLUSION}

In this study, we discussed the effect of vitamin D and its synergism influence on some biochemical parameters in patients with T2DM by an interventional and experimental observation. Furthermore, we investigated the possibility of synergism effects of metformin on vitamin D function by employing molecular modeling methods and computational biology. In the experimental phase, our data showed that the combination of vitamin D/ metformin or vitamin D/ insulin treatments caused a decrease in FBS. Furthermore, these treatments lead to an increase in calcium of patient serum. Also, based on our results, vitamin D in all groups reduced the concentration of LDL and cholesterol but had no significant effects on serum triglyceride. The best decrease in the insulin resistance was found in group III, who treated with vitamin D and insulin. The level of GLUT4 expression and its trafficking have not been found in the lymphocytes of healthy people or patients with T1DM. However, our flow cytometry and real-time PCR data demonstrated that the patients with T2DM exhibited the increase in the expression of GLUT4 and its emerging on the lymphocytes surface. In group II who treated with vitamin D and metformin, the level of GLUT4 mRNA and its translocation from cytosol to lymphocyte plasma membrane have been decreased significantly. Nearly all biological functions of vitamin D are mediated by its binding to VDR. Then, the activated VDR interacts with co-activator protein and the formed 
complex bind to hormone response elements in DNA. So, we postulated that based on our experimental results, a synergism exists between vitamin D and metformin. To evaluate our hypothesis, and for the first time, we employed the molecular docking, MD simulations, and QM/MM calculations to analyze some thermodynamic and quantum parameters. RMSF values showed that in the presence of metformin, vitamin D -bound VDR has higher flexibility (in comparison with free VDR). Amino acid residues 413-419 are critical residues located in helix 12 and form LBD. RMSF analysis exhibited that in the vitamin D -bound VDR, the flexibilities of Leu 415, Glu 416 and Phe 418, in comparison with free VDR are reduced. However, in the presence of metformin, vitamin D: VDR complex showed lower flexibilities in the residues mentioned above. In the "folding-door model", Gly 419 from helix 12 comes near to helix 11 due to interaction with Tyr 397. Based on our results, the RMSF value of Tyr 397 in vitamin D: VDR or vitamin D: VDR: metformin was lower than free VDR. This reduction could be the result of interaction with Gly 419 from helix 12. Due to an interaction of helix 12 with co-activator protein, the RMSF values of co-activator residues in ligand-bound VDR were remarkably lower than unbound VDR. MD simulation during $50 \mathrm{~ns}$ showed that one of the metformin molecules interacts with Asp 353 through two hydrogen bonds. We suggest that this interaction could affect the 3D structure of vitamin D bound VDR and stimulates it to interact more efficiency with co-activator protein. The QM/MM-derived binding free energies for vitamin D in VDR in the presence and absence of metformin were -25.24 and $24.39 \mathrm{kcal} / \mathrm{mol}$, respectively. In the presence of metformin, HOMO and LUMO of vitamin D in the bounded state were lower, which exhibits the higher agonist activity. The metformin included in the vitamin D: VDR system also changed the computed vibrational spectrum of agonist with regard to MD simulations, MM-PBSA and QM/MM computation, in the presence of metformin, the free binding energy between vitamin D and VDR is reduced. So, metformin makes vitamin $\mathrm{D}$ to be a more potent VDR agonist.

\section{MATERIALS AND METHODS}

\subsection{Study design and human groups}

Interventional and experimental studies were performed on adult diabetic patients. A total of 45 volunteer patients, 24 males and 21 females were included in this study. The study was conducted under the supervision of an endocrine and metabolism physician in the Shahid Rajaie Hospital of Qazvin during the period from June 2017 to July 2017 for two months. All experimental stages of this study were done based on ethical considerations and patient consent letter with permission from the ethical committee of the Shahid Rajaie Hospital of Qazvin. According to the type of treatment, patients were randomly divided into three groups (15 patients/group): Group I: patients who were treated with a diet containing fibers and proteins with limited carbohydrates or lipids (they were selected randomly). Group II: patients who were treated with metformin 500 mg daily. Group III: patients who were treated with 30U NPH insulin daily. Before any treatment, all patients were controlled for four months. After the first measurements, vitamin D3 (50,000 units once a week) was added to the three groups for two months. Then, the measurements were repeated again. The results after and before the treatments with vitamin D3 were analyzed and compared with each other. All the patients were interviewed and detailed history was obtained.

\subsection{Biochemical methods}

\subsubsection{Quantitative biochemical parameters of serum}

Glucose, LDL, HDL, triglyceride, cholesterol, calcium, phosphorous and magnesium were measured by PARS AZMOON kits and autoanalyzer SELECTRA E. The level of vitamin D3 in the serum was calculated by pishtazteb kit and stat fax 4200 microplate reader. For insulin assay, Insulin ELISA Kits from R\&D Systems were employed. Potassium and sodium of patient serum were measured by flame photometer EFOX 5054 (Eppendorf, Germany) and electrolyte analyzer (ISE XD 68X, China). All parameters were measured according to the manufacturer's instruction of the relevant kits. 


\subsubsection{Lymphocyte isolation}

$5 \mathrm{~mL}$ of heparin anti-coagulated blood samples were obtained from 45 adult patient donors. $5 \mathrm{~mL}$ of normal saline was added to the blood sample and smoothly was shaken. Then, $8 \mathrm{~mL}$ of diluted blood was poured to $3 \mathrm{~mL}$ of ficoll solution followed by centrifugation at $3000 \mathrm{rpm}$ for 20 minutes. The layer containing lymphocytes was isolated and the equal volume of cold normal saline was added to it. After centrifugation at $2500 \mathrm{rpm}$ for 5 minutes, the supernatant was disposed of, and the cells were re-suspended in $0.5 \mathrm{~mL}$ of cold normal saline. Finally, the isolated cells were kept in a cold room for further analysis.

\subsubsection{Lymphocyte viability test}

The test was directed to confirm the survival of the cells during the experiment. 1\% solution of trypan blue was added to the isolated suspension cells at 1:1 volume ratio. The number of dead lymphocytes in a sample of 500 cells was counted using the hemocytometer and a light microscope.

\subsubsection{Investigation of the presence of GLUT4 on the lymphocyte surface with flow cytometry}

As previously described by Oleszczak et al. approximately, $2.5 \times 10^{5}$ isolated lymphocytes $\mathrm{T}$ were washed in $2 \mathrm{~mL}$ of the washing buffer for flow cytometry (PBS lacking $\mathrm{Mg}^{2+}$ and $\mathrm{Ca}^{2+}$, along with 2 percent fetal bovine serum and $2 \times 10^{-3}$ percent sodium azide) by centrifugation at $4^{\circ} \mathrm{C}$ and $250 \mathrm{~g}$. then, it suspended in 100 $\mathrm{mL}$ of the buffer. To increase the permeability of lymphocytes $\mathrm{T}$ membranes, the cells were incubated for $5 \mathrm{~min}$ with $0.1 \mathrm{~mL}$ Perm 2 (Becton - Dickinson) [43]. Then, $2 \mu \mathrm{L}$ of a monoclonal antibody, labeled with FITC (GLUT4 IF8: SC-53566 SANTA CRUZ BIOTECHNOLOGY, INC), was added to the cells and incubated. The cells were then washed in the buffer for flowcytometery. Following the incubation, $2 \mathrm{~mL}$ of washing buffer was added to each sample. After that, the resulting suspensions were centrifuged at $4^{\circ} \mathrm{C}$ and $250 \mathrm{~g}$. In the next step, the supernatant was discarded and $0.5 \mathrm{~mL}$ of the washing buffer and 1 percent formaldehyde were added. The samples were examined by the FACS Calibur flow cytometer (Becton - Dickinson) equipped with an argon laser (wavelength of $488 \mathrm{~nm}$ ), utilizing the CellQuest software [43].

\subsubsection{Total RNA extraction from lymphocytes}

Total RNA was extracted from isolated lymphocytes using RNA Extraction kit (IraiZol) (Zist Fanavaran, Iran) based on manufacturer's instruction. The concentrations and purity of extracted RNA were assessed with a NanoDrop spectrophotometer (Thermo Scientific Co).

\subsubsection{Complementary DNA (cDNA) synthesis}

$4 \mu \mathrm{g}$ of total extracted RNA in the previous step was mixed with $1 \mu \mathrm{L}(1 \mu \mathrm{g} / \mu \mathrm{L})$ random primers and 10 $\mathrm{mM}$ dNTP mix, in a total volume of $15 \mu \mathrm{L}$. Afterwards, the mixture was incubated at $56^{\circ} \mathrm{C}$ for 5 minutes, and then placed on ice for $3 \mathrm{~min}$. The reverse transcriptase master mix including $3 \mu \mathrm{L}$ of $5 \times \mathrm{RT}$ buffer, and $0.5 \mu \mathrm{L}$ of M-MLV RT $(100 \mathrm{U} / \mu \mathrm{L})$ was poured to the mixture and was incubated at $50^{\circ} \mathrm{C}$ for 50 minutes followed by 15 minutes at $72^{\circ} \mathrm{C}$.

\subsubsection{Real-time quantitative PCR}

Real-time PCR amplification and analysis were carried out by an Applied Biosystem with software version 3.1 (StepOne $^{\mathrm{TM}}$, USA). The reaction contained SYBR Green qPCR Mix (Applied Biosystems), genespecific primer pairs for GLUT4 which were shown in Table 4, were designed by Allele ID v. 6.0 from RNA sequences from the gene bank. The relevant primers for B actin were retrieved from the literature [1]. Quantitative RT-PCR was accomplished in a 25- $\mu$ l reaction volume containing 2X RB SYBR Green qPCR Master Mix (Applied Biosystems), $10 \mathrm{pM}$ of each primer and $3 \mu \mathrm{l}$ of cDNA. Amplification conditions were: $10 \mathrm{~min}$ at $95^{\circ}$, $15 \mathrm{~s}$ at $95^{\circ}, 20 \mathrm{~s}$ at $55^{\circ}, 20 \mathrm{~s}$ at $65^{\circ}$ and 40 cycles of denaturation. The real-time outputs were computed by the v1 7 sequence detection software from PE Biosystems (Foster City, CA). Relative expression of studied gene mRNA was calculated using the comparative $\mathrm{Ct}$ method. In the last step, all values were normalized to the beta-actin (a housekeeping gene) [1]. 
Table 4. Oligonucleotide primers sequence of the studied genes. The primer of B-actin gene was taken from literature [1].

\begin{tabular}{cc}
\hline Sequence $\left(5^{\prime}\right.$ to $\left.3^{\prime}\right)$ & Oligonucleotide Name \\
\hline GLUT4 Forward & GAC TAC TCA GGG CTG ACA TCA G \\
GLUT4 Reverse & TCA CCT GGG CGA TCA GAA TG \\
Beta Actin Reverse & TGCTGGTGCTGAGTATGTCG \\
Beta Actin Reverse & TTGAGAGCAATGCCAGCC \\
\hline
\end{tabular}

\subsubsection{Calculation of insulin resistance and insulin sensitivity}

To estimate the degree of insulin resistance, the formula of Homeostatic model assessment (HOMA-IR) was employed [44]:

HOMA-IR = fasting plasma insulin $\times$ FBS $/ 22.5$

To compute the degree of insulin sensitivity, the formula of quantitative insulin-sensitivity check index (QUICKI) was occupied [45]:

QUICKI $=1 /[\log ($ fasting insulin, $1 \mathrm{U} / \mathrm{mL}) \log (\mathrm{FBS}, \mathrm{mg} / \mathrm{dL})]$

\subsection{Statistical analyses}

Data analysis was performed using SPSS version 16 (SPSS Inc., Chicago, IL). p values < 0.05 were considered statistically significant [1]. For quantitative comparison the averages between before and after treatment in each group, Paired T-Test was employed. Data were expressed as mean \pm SD.

\subsection{Molecular modeling phase}

\subsubsection{Homology modeling of VDR and loop refinement}

The 3D structure of VDR, with PDB code of 2zlc, was taken from the protein data bank and employed for molecular docking and MD studies. The important missing residues of the structure were 160-170 residues. All the missing residues were modeled by MODELLER [46]. After the insertion of missing residues, loop refinement was employed with ab initio approach. In the occupied method, the loop was removed initially, reconstructed by a specific method, and then thoroughly sampled it to recognize the conformation with the lowest energy. Usually, refining the loops with less than nine residues long produces the outstanding outputs. For the loops with 10 to 12 residues long, it gives reasonable results.

\subsubsection{Molecular docking of vitamin D into the VDR}

Docking is a tool for predicting the preferred direction of one molecule to another when bound to each other and constitute an energetically stable complex [47]. The 3D structure of vitamin D was sketched with HyperChem Version 8.0 (HyperCube Inc) followed by MM+ (molecular mechanics) and PM3 (semi-empirical) minimization and optimization. The docking of vitamin D into the binding site of VDR was done by AutoDock Vina [48] (Figure 12). This docking software works based on the empirical scoring functions, and is capable to compute the grid maps automatically. For molecular docking runs, the default parameters were allocated. In each docking run, the pose with the lowest binding energy was chosen for MD study [47]. 


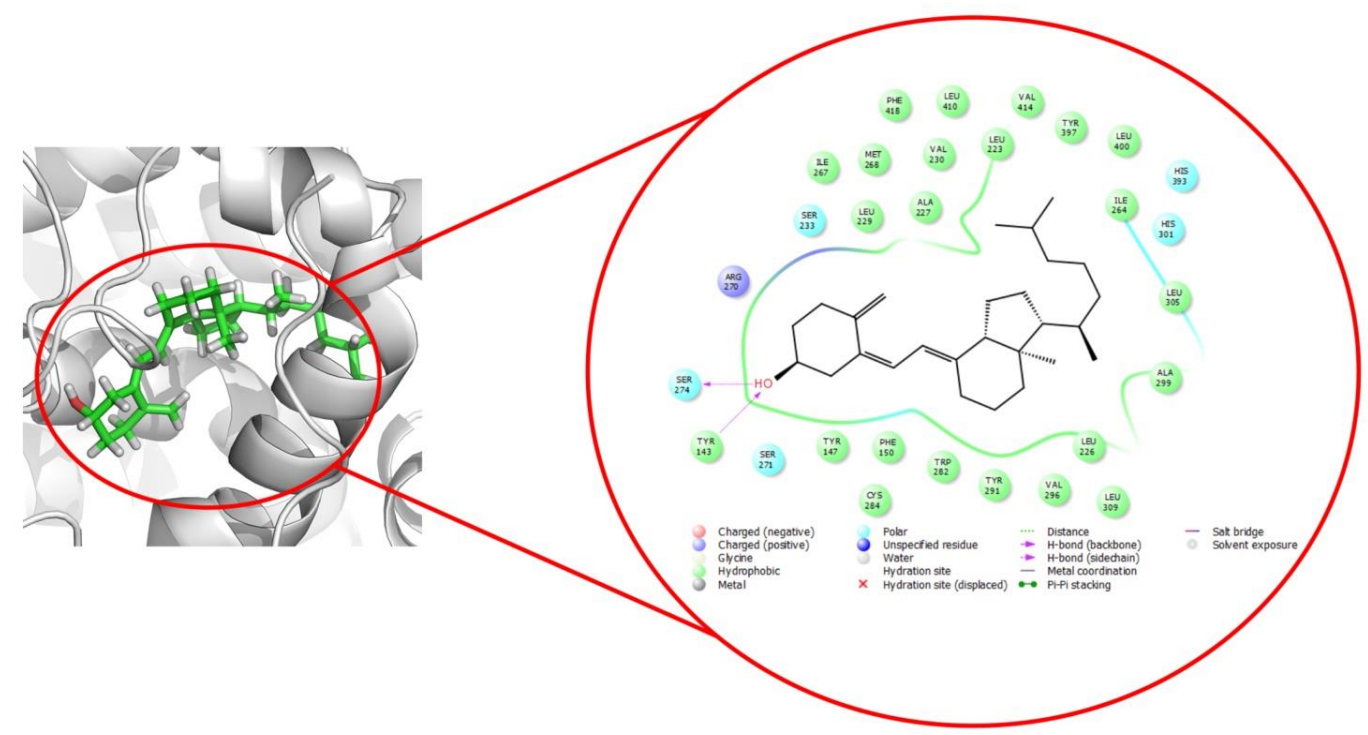

Figure 12. The binding mode of vitamin $\mathrm{D}$ in the active site of VDR, computed by AutoDock Vina. In the right side, hydrogen bonds between the hydroxyl moeitey of vitamin D and VDR residues are shown as dashed arrow.

\subsubsection{MD simulation on VDR}

Three independent MD runs were conducted for free VDR, VDR: vitamin D and VDR: vitamin D: metformin complexes. In the last system, totally six molecules of metformin were assigned in the MD box. The MD runs were performed with GROMACS 5.1 package and AMBER 99SB force field [47, 49]. PROPKA 2.0 server [50] was occupied to calculate the $\mathrm{pKa}$ of VDR residues and assigning the proper ionization states of VDR ionizing groups. The partial charges and topology files of vitamin D and metformin were prepared by ACPYPE, a tool established on ANTECHAMBER [51-53]. With regard to the selected Amber force field in all our MD simulations, the compatible TIP3P water model in a cubic periodic box was employed. Each system was minimized energetically with the steepest descent integrator followed by conjugate gradient algorithm to achieve a maximum force below $1000 \mathrm{~kJ} \mathrm{~mol}^{-1} \mathrm{~nm}^{-1}$ on any atom. The cutoff for computing the short-range, nonbonded interactions of van der Waals and electrostatic interactions were assigned 1.4 and $0.9 \mathrm{~nm}$, respectively. Particle mesh Ewald (PME) algorithm was operated to treat the Long-range electrostatic interactions [54, 55]. The temperature of $300 \mathrm{~K}$, with the coupling time constant of $0.1 \mathrm{ps}$ [56], and pressure of 1 bar (coupling constant of 2 ps) [57] was assigned for each MD run. A Berendsen coupling with an additional term [49], and Parrinello-Rahman barostat [57] were used for temperature and pressure coupling, respectively. To restrict the bond lengths with a 2 fs time step, Linear Constraint Solver (LINCS) was occupied [58]. Each system was equilibrated under a constant volume (NVT) ensemble (100 ps) and a constant pressure (NPT) ensemble (100 ps) [47]. The equilibrated system from each run was subjected to $50 \mathrm{~ns}$ MD simulation. Visual molecular dynamics (VMD) [59], PyMOL [60] and standard tools implemented in the GROMACS package were occupied to analyze the trajectories.

\subsubsection{Estimation of the binding free energy of VDR complexes with MM-PBSA algorithm}

MM-PBSA (Molecular Mechanics-Poisson-Boltzmann or Generalized Born solvent-accessible Surface Area) is an open-source package. MMPBSA is a useful tool for the calculation of inter-molecular interactions [61]. After the completion of each MD run, the inter-molecular average binding free energy $\left(\Delta \mathrm{G}_{\text {binding }}\right)$ between vitamin D and VDR (in the presence or absence of metformin) was computed by MM-PBSA. 
The binding free energy is based on the following theory:

$\Delta \mathrm{G}_{\text {binding }}=\mathrm{G}_{\text {complex }}-\left(\mathrm{G}_{\text {protein }}+\mathrm{G}_{\text {ligand }}\right)$

Where $\mathrm{G}_{\text {complex }}$ is the total free energy of the protein-ligand complex [62], and $\mathrm{G}_{\text {protein }}$ and $\mathrm{G}_{\text {ligand }}$ are total free energies of the separated form of protein and ligand in solvent, respectively [61, 63].

\subsubsection{Quantum mechanics/molecular mechanics (QM/MM)}

The density functional theory (DFT) calculations were conducted by Jaguar implemented in Schrödinger's Maestro Molecular modeling package [41]. The vitamin D molecule was processed at the quantum mechanical (QM) level, and the VDR and metformin at the MM level. Vitamin D was optimized in free, VDR and metformin-VDR bound states, with hybrid DFT using Becke's three parameter exchange potential and Lee-YangParr correlation functional (B3LYP) gradient corrected exchange-correlation functional in combination [40] with 6-31 $\mathrm{G}^{*}$ basis set $[64,65]$. In the case of Vitamin D bound VDR, the complex from the last snapshot of MD was introduced to QM/MM calculations. OPLS 2005 force field was selected in the MM part of QM/MM studies [41]. Highest occupied molecular orbital (HOMO), lowest unoccupied molecular orbital (LUMO) and energy gaps were calculated. The free binding energy of the complex was computed using the following formula:

$E_{\text {binding }}=E_{\text {complex }}-E_{\text {free_receptor- }}$ Efree_ligand

(Eq. 4)

Author contributions: Concept - F.A., M.A., M.M., S.M., L.G.; Design - M.A.; Supervision - M.M.; Materials S.M; Data Collection and/or Processing - F.A., M.A., M.M., S.M., L.G.; Analysis and/or Interpretation - F.A.; Literature Search - S.M.; Writing - F.A.; Critical Reviews - F.A., M.A., M.M., S.M., L.G.

Conflict of interest statement: The authors report that they have no conflicts of interest.

\section{REFERENCES}

[1] Amin SN, Hussein UK, Yassa HD, Hassan SS, Rashed LA. Synergistic actions of Vitamin D and metformin on skeletal muscles and insulin resistance of Type 2 diabetic rats. J Cell Physiol. 2018; 233(8): 5768-5779. [CrossRef]

[2] Vos T, Flaxman AD, Naghavi M, Lozano R, Michaud C, Ezzati M, Shibuya K, Salomon JA, Abdalla S, Aboyans V, Abraham J, Ackerman I, Aggarwal R, Ahn SY, Ali MK, Alvarado M, Anderson HR, Anderson LM, Andrews KG, Atkinson C, Baddour LM, Bahalim AN, Barker-Collo S, Barrero LH, Bartels DH, Basáñez MG, Baxter A, Bell ML, Benjamin EJ, Bennett D, Bernabé E, Bhalla K, Bhandari B, Bikbov B, Bin Abdulhak A, Birbeck G, Black JA, Blencowe H, Blore JD, Blyth F, Bolliger I, Bonaventure A, Boufous S, Bourne R, Boussinesq M, Braithwaite T, Brayne C, Bridgett L, Brooker S, Brooks P, Brugha TS, Bryan-Hancock C, Bucello C, Buchbinder R, Buckle G, Budke CM, Burch M, Burney P, Burstein R, Calabria B, Campbell B, Canter CE, Carabin H, Carapetis J, Carmona L, Cella C, Charlson F, Chen H, Cheng AT, Chou D, Chugh SS, Coffeng LE, Colan SD, Colquhoun S, Colson KE, Condon J, Connor MD, Cooper LT, Corriere M, Cortinovis M, de Vaccaro KC, Couser W, Cowie BC, Criqui MH, Cross M, Dabhadkar KC, Dahiya M, Dahodwala N, Damsere-Derry J, Danaei G, Davis A, De Leo D, Degenhardt L, Dellavalle R, Delossantos A, Denenberg J, Derrett S, Des Jarlais DC, Dharmaratne SD, Dherani M, Diaz-Torne C, Dolk H, Dorsey ER, Driscoll T, Duber H, Ebel B, Edmond K, Elbaz A, Ali SE, Erskine H, Erwin PJ, Espindola P, Ewoigbokhan SE, Farzadfar F, Feigin V, Felson DT, Ferrari A, Ferri CP, Fèvre EM, Finucane MM, Flaxman S, Flood L, Foreman K, Forouzanfar MH, Fowkes FG, Franklin R, Fransen M, Freeman MK, Gabbe BJ, Gabriel SE, Gakidou E, Ganatra HA, Garcia B, Gaspari F, Gillum RF, Gmel G,Gosselin R, Grainger R, Groeger J, Guillemin F, Gunnell D, Gupta R, Haagsma J, Hagan H, Halasa YA, Hall W, Haring D, Haro JM, Harrison JE, Havmoeller R, Hay RJ, Higashi H, Hill C, Hoen B, Hoffman H, Hotez PJ, Hoy D, Huang JJ, Ibeanusi SE, Jacobsen KH, James SL, Jarvis D, Jasrasaria R, Jayaraman S, Johns N, Jonas JB, Karthikeyan G, Kassebaum N, Kawakami N, Keren A, Khoo JP, King CH, Knowlton LM, Kobusingye O, Koranteng A, Krishnamurthi R, Lalloo R, Laslett LL, Lathlean T, Leasher JL, Lee YY, Leigh J, Lim SS, Limb E, Lin JK, Lipnick M, Lipshultz SE, Liu W, Loane M, Ohno SL, Lyons R, Ma J, Mabweijano J, MacIntyre MF, Malekzadeh R, Mallinger L, Manivannan S, Marcenes W, March L, Margolis DJ, Marks GB, Marks R, Matsumori A, Matzopoulos R, Mayosi BM, McAnulty JH, McDermott MM, McGill N, McGrath J, Medina-Mora ME, Meltzer M, Mensah GA, Merriman TR, Meyer AC, Miglioli V, Miller M, Miller TR, Mitchell PB, Mocumbi AO, Moffitt TE, Mokdad AA, Monasta L, Montico M, Moradi-Lakeh M, Moran A, Morawska L, 
Mori R, Murdoch ME, Mwaniki MK, Naidoo K, Nair MN, Naldi L, Narayan KM, Nelson PK, Nelson RG, Nevitt MC, Newton CR, Nolte S, Norman P, Norman R, O'Donnell M, O'Hanlon S, Olives C, Omer SB, Ortblad K, Osborne R, Ozgediz D, Page A, Pahari B, Pandian JD, Rivero AP, Patten SB, Pearce N, Padilla RP, Perez-Ruiz F, Perico N, Pesudovs K, Phillips D, Phillips MR, Pierce K, Pion S, Polanczyk GV, Polinder S, Pope CA 3rd, Popova S, Porrini E, Pourmalek F, Prince M, Pullan RL, Ramaiah KD, Ranganathan D, Razavi H, Regan M, Rehm JT, Rein DB, Remuzzi G, Richardson K, Rivara FP, Roberts T, Robinson C, De Leòn FR, Ronfani L, Room R, Rosenfeld LC, Rushton L, Sacco RL, Saha S, Sampson U, Sanchez-Riera L, Sanman E, Schwebel DC, Scott JG, Segui-Gomez M, Shahraz S, Shepard DS, Shin H, Shivakoti R, Singh D, Singh GM, Singh JA, Singleton J, Sleet DA, Sliwa K, Smith E, Smith JL, Stapelberg NJ, Steer A, Steiner T, Stolk WA, Stovner LJ, Sudfeld C, Syed S, Tamburlini G, Tavakkoli M, Taylor HR, Taylor JA, Taylor WJ, Thomas B, Thomson WM, Thurston GD, Tleyjeh IM, Tonelli M, Towbin JA, Truelsen T, Tsilimbaris MK, Ubeda C, Undurraga EA, van der Werf MJ, van Os J, Vavilala MS, Venketasubramanian N, Wang M, Wang W, Watt K, Weatherall DJ, Weinstock MA, Weintraub R, Weisskopf MG, Weissman MM, White RA, Whiteford H, Wiersma ST, Wilkinson JD, Williams HC, Williams SR, Witt E, Wolfe F, Woolf AD, Wulf S, Yeh PH, Zaidi AK, Zheng ZJ, Zonies D, Lopez AD, Murray CJ, AlMazroa MA, Memish ZA. Years lived with disability (YLDs) for 1160 sequelae of 289 diseases and injuries 1990-2010: A systematic analysis for the global burden of disease study 2010. Lancet. 2013; 380(9859): 21632196. [CrossRef]

[3] Michaelides A, Raby C, Wood M, Farr K, Toro-Ramos T. Weight loss efficacy of a novel mobile Diabetes Prevention Program delivery platform with human coaching. BMJ Open Diabetes Res Care. 2016; 4(1): e000264. [CrossRef]

[4] Wang Z, Wang J, Chan P. Treating type 2 diabetes mellitus with traditional Chinese and Indian medicinal herbs. Evid Based Complement Alternat Med. 2013; Article ID 343594. [CrossRef]

[5] Pradeep T, Haranath C. A Review on Diabetes Mellitus Type II. Int J Pharm Res Rev. 2014; 3(9): $23-29$.

[6] Li W, Zheng H, Bukuru J, De Kimpe N. Natural medicines used in the traditional Chinese medical system for therapy of diabetes mellitus. J Ethnopharmacol. 2004; 92(1): 1-21. [CrossRef]

[7] Gunton JE, Delhanty PJ, Takahashi S-I, Baxter RC. Metformin rapidly increases insulin receptor activation in human liver and signals preferentially through insulin-receptor substrate-2. J Clin Endocrinol Metab. 2003; 88(3): $1323-1332$. [CrossRef]

[8] Maida A, Lamont B, Cao X, Drucker D. Metformin regulates the incretin receptor axis via a pathway dependent on peroxisome proliferator-activated receptor- $\alpha$ in mice. Diabetologia. 2011; 54(2): 339-349. [CrossRef]

[9] Cusi K, Consoli A, Defronzo RA. Metabolic effects of metformin on glucose and lactate metabolism in noninsulindependent diabetes mellitus. J Clin Endocrinol Metab. 1996; 81(11): 4059-4067. [CrossRef]

[10] Hundal RS, Krssak M, Dufour S, Laurent D, Lebon V, Chandramouli V, Inzucchi SE, Schumann WC, Petersen KF, Landau BR, Shulman GI.Mechanism by which metformin reduces glucose production in type 2 diabetes. Diabetes. 2000; 49(12): 2063-2069. [CrossRef]

[11] Natali A, Ferrannini E. Effects of metformin and thiazolidinediones on suppression of hepatic glucose production and stimulation of glucose uptake in type 2 diabetes: a systematic review. Diabetologia. 2006; 49(3): 434-441. [CrossRef]

[12] Szablewski L, Sobczyk-Kopcioł A, Oleszczak B, Nowak Ł, Grytner-Zięcina B. GLUT 4 is expressed in circulating lymphocytes of diabetic patients. A method to detect early prediabetic stages. Diabetol Croat. 2007; 36(suppl 4): 69-76.

[13] Huang S, Czech MP. The GLUT4 glucose transporter. Cell Metab. 2007; 5(4): 237-252. [CrossRef]

[14] Bryant NJ, Govers R, James DE. Regulated transport of the glucose transporter GLUT4. Nat Rev Mol Cell Biol. 2002; 3(4): 267-277. [CrossRef]

[15] Mattila C, Knekt P, Männistö S, Rissanen H, Laaksonen MA, Montonen J, Reunanen A. Serum 25-hydroxyvitamin D concentration and subsequent risk of type 2 diabetes. Diabetes Care. 2007; 30(10): 2569-2570. [CrossRef]

[16] Palomer X, González-Clemente J, Blanco-Vaca F, Mauricio D. Role of vitamin D in the pathogenesis of type 2 diabetes mellitus. Diabetes Obes Metab. 2008; 10(3): 185-197. [CrossRef]

[17] Maestro B, Molero S, Bajo S, Davila N, Calle C. Transcriptional activation of the human insulin receptor gene by 1, 25dihydroxyvitamin D3. Cell Biochem Funct. 2002; 20(3): 227-232. [CrossRef] 
[18] Yamamoto K, Masuno H, Choi M, Nakashima K, Taga T, Ooizumi H, Umesono K, Sicinska W, VanHooke J, DeLuca HF, Yamada S. Three-dimensional modeling of and ligand docking to vitamin D receptor ligand binding domain. Proc Natl Acad Sci U S A. 2000; 97(4): 1467-1472. [CrossRef]

[19] Johnson JA, Grande JP, Roche PC, Kumar R. Immunohistochemical localization of the 1, 25 (OH) $2 \mathrm{D} 3$ receptor and calbindin D28k in human and rat pancreas. Am J Physiol Endocrinol Metab. 1994; 267(3): E356-E360. [CrossRef]

[20] Bland R, Markovic D, Hills CE, Hughes SV, Chan SL, Squires PE, Hewison M. Expression of 25-hydroxyvitamin D 3-1ahydroxylase in pancreatic islets. J Steroid Biochem Molec Biol. 2004; 89: 121-125. [CrossRef]

[21] Maestro B, Dávila N, Carranza MC, Calle C. Identification of a Vitamin D response element in the human insulin receptor gene promoter. J Steroid Biochem Mol Biol. 2003; 84(2): 223-230. [CrossRef]

[22] Gupta T, Rawat M, Gupta N, Arora S. Study of effect of Vitamin D supplementation on the clinical, hormonal and metabolic profile of the PCOS women. J Obstet Gynaecol India. 2017; 1-7. [CrossRef]

[23] Khattab AAA. Tei index in neonatal respiratory distress and perinatal asphyxia. Egypt Heart J. 2015; 67(3): 243-248. [CrossRef]

[24] Wimalawansa SJ, Razzaque DMS, Al-Daghri NM. Calcium and vitamin D in human health: Hype or real? J Steroid Biochem Mol Biol. 2018; 180: 4-14. [CrossRef]

[25] Jorde R, Grimnes G. Vitamin D and metabolic health with special reference to the effect of vitamin D on serum lipids. Prog Lipid Res. 2011; 50(4): 303-312. [CrossRef]

[26] Blumberg JM, Tzameli I, Astapova I, Lam FS, Flier JS, Hollenberg AN. Complex role of the vitamin D receptor and its ligand in adipogenesis in 3T3-L1 cells. J Biol Chem. 2006; 281(16): 11205-11213. [CrossRef]

[27] Kong J, Li YC. Molecular mechanism of 1, 25-dihydroxyvitamin D3 inhibition of adipogenesis in 3T3-L1 cells. Am J Physiol Endocrinol Metab. 2006; 290(5): E916-E924. [CrossRef]

[28] Shepherd PR, Gnudi L, Tozzo E, Yang H, Leach F, Kahn BB. Adipose cell hyperplasia and enhanced glucose disposal in transgenic mice overexpressing GLUT4 selectively in adipose tissue. J Biol Chem. 1993; 268(30): 22243-22246.

[29] Tozzo E, Shepherd PR, Gnudi L, Kahn BB. Transgenic GLUT-4 overexpression in fat enhances glucose metabolism: preferential effect on fatty acid synthesis. Am J Physiol Endocrinol Metab. 1995; 268(5): E956-E964. [CrossRef]

[30] Tsao T-S, Li J, Chang KS, Stenbit AE, Galuska D, Anderson JE, Zierath JR, McCarter RJ, Charron MJ. Metabolic adaptations in skeletal muscle overexpressing GLUT4: effects on muscle and physical activity. FASEB J. 2001; 15(6): 958969. [CrossRef]

[31] Abel ED, Peroni O, Kim JK, Kim Y-B, Boss O, Hadro E, Minnemann T, Shulman GI, Kahn BB. Adipose-selective targeting of the GLUT4 gene impairs insulin action in muscle and liver. Nature. 2001; 409(6821): 729-733. [CrossRef]

[32] Zisman A, Peroni OD, Abel ED, Michael MD, Mauvais-Jarvis F, Lowell BB, Wojtaszewski JF, Hirshman MF, Virkamaki A, Goodyear LJ, Kahn CR, Kahn BB. Targeted disruption of the glucose transporter 4 selectively in muscle causes insulin resistance and glucose intolerance. Nat Med. 2000; 6(8): 924-928. [CrossRef]

[33] Salsbury FR. Molecular dynamics simulations of protein dynamics and their relevance to drug discovery. Curr Opin Pharmacol. 2010; 10(6): 738-744. [CrossRef]

[34] Väisänen S, Peräkylä M, Kärkkäinen JI, Steinmeyer A, Carlberg C. Critical role of helix 12 of the vitamin D 3 receptor for the partial agonism of carboxylic ester antagonists. J Mol Biol. 2002; 315(2): 229-238. [CrossRef]

[35] Liu Y-Y, Nguyen C, Peleg S. Regulation of ligand-induced heterodimerization and coactivator interaction by the activation function-2 domain of the vitamin D receptor. Mol Endocrinol. 2000; 14(11): 1776-1787. [CrossRef]

[36] Nayeri S, Kahlen J-P, Carlberg C. The high affinity ligand binding conformation of the nuclear 1, 25-dihydroxyvitamin D 3 receptor is functionally linked to the transactivation domain 2 (AF-2). Nucleic Acids Res. 1996; 24(22): $4513-4518$. [CrossRef]

[37] Anami Y, Shimizu N, Ekimoto T, Egawa D, Itoh T, Ikeguchi M, Yamamoto K. Apo-and antagonist-binding structures of vitamin $\mathrm{D}$ receptor ligand-binding domain revealed by hybrid approach combining small-angle X-ray scattering and molecular dynamics. J Med Chem. 2016; 59(17): 7888-7900. [CrossRef] 
[38] Banaganapalli B, Mulakayala C, Gowsia D, Mulakayala N, Pulaganti M, Shaik NA, Cm A, Rao RM, Al-Aama JY, Chitta SK. Synthesis and biological activity of new resveratrol derivative and molecular docking: Dynamics studies on NFkB. Appl Biochem Biotechnol. 2013; 171(7): 1639-1657. [CrossRef]

[39] Arooj M, Thangapandian S, John S, Hwang S, Park JK, Lee KW. 3D QSAR pharmacophore modeling, in silico screening, and density functional theory (DFT) approaches for identification of human chymase inhibitors. Int J Mol Sci. 2011; 12(12): 9236-9264. [CrossRef]

[40] Rajamanikandan S, Jeyakanthan J, Srinivasan P. Discovery of potent inhibitors targeting Vibrio harveyi LuxR through shape and e-pharmacophore based virtual screening and its biological evaluation. Microb Pathog. 2017; 103: 40-56. [CrossRef]

[41] Ardalan N, Mirzaie S, Sepahi AA, Khavari-Nejad RA. Novel mutant of Escherichia coli asparaginase II to reduction of the glutaminase activity in treatment of acute lymphocytic leukemia by molecular dynamics simulations and QM-MM studies. Med Hypotheses. 2018; 12: 7-17. [CrossRef]

[42] Selvaraman N, Selvam SK, Muthusamy K. The binding mode prediction and similar ligand potency in the active site of vitamin D receptor with QM/MM interaction, MESP, and MD simulation. Chem Biol Drug Des. 2016; 88(2): 272-280. [CrossRef]

[43] Oleszczak B, Szablewski L, Pliszka M. The effect of hyperglycemia and hypoglycemia on glucose transport and expression of glucose transporters in human lymphocytes B and T: An in vitro study. Diabetes Res Clin Pract. 2012; 96(2): 170-178. [CrossRef]

[44] Haljas K, Amare AT, Alizadeh BZ, Hsu Y-H, Mosley T, Newman A, Murabito J, Tiemeier H, Tanaka T, van Duijn C, Ding J, Llewellyn DJ, Bennett DA, Terracciano A, Launer L, Ladwig KH, Cornelis MC, Teumer A, Grabe H, Kardia SLR, Ware EB, Smith JA, Snieder H, Eriksson JG, Groop L, Räikkönen K, Lahti J. Bivariate genome-wide association study of depressive symptoms with Type 2 diabetes and quantitative glycemic traits. Psychosom Med. 2018; 80(3): 242251. [CrossRef]

[45] Seyyed Abootorabi M, Ayremlou P, Behroozi-Lak T, Nourisaeidlou S. The effect of vitamin D supplementation on insulin resistance, visceral fat and adiponectin in vitamin D deficient women with polycystic ovary syndrome: a randomized placebo-controlled trial. Gynecol Endocrinol. 2018; 34(6): 489-494. [CrossRef]

[46] Šali A, Blundell TL. Comparative protein modelling by satisfaction of spatial restraints. J Mol Biol. 1993; $234(3):$ 779-815. [CrossRef]

[47] Karami M, Jalali C, Mirzaie S. Combined virtual screening, MMPBSA, molecular docking and dynamics studies against deadly anthrax: An in silico effort to inhibit Bacillus anthracis nucleoside hydrolase. J Theor Biol. 2017; 420: 180-189. [CrossRef]

[48] Trott O, Olson AJ. AutoDock Vina: improving the speed and accuracy of docking with a new scoring function, efficient optimization, and multithreading. J Comput Chem. 2010; 31(2): 455-461. [CrossRef]

[49] Van Der Spoel D, Lindahl E, Hess B, Groenhof G, Mark AE, Berendsen HJ. GROMACS: fast, flexible, and free. J Comput Chem. 2005; 26(16): 1701-1718. [CrossRef]

[50] Bas DC, Rogers DM, Jensen JH. Very fast prediction and rationalization of pKa values for protein-ligand complexes. Proteins. 2008; 73(3): 765-783. [CrossRef]

[51] Wang J, Wang W, Kollman PA, Case DA. Antechamber: an accessory software package for molecular mechanical calculations. J Comput Chem. 2005; 25: 1157-1174.

[52] Wang J, Wang W, Kollman PA, Case DA. Automatic atom type and bond type perception in molecular mechanical calculations. J Mol Graph Model. 2006; 25(2): 247-260. [CrossRef]

[53] Wang J, Wolf RM, Caldwell JW, Kollman PA, Case DA. Development and testing of a general amber force field. J Comput Chem. 2004; 25(9): 1157-1174. [CrossRef]

[54] Darden T, York D, Pedersen L. Particle mesh Ewald: An N. log (N) method for Ewald sums in large systems. J Chem Phys. 1993; 98(12): 10089-10092. [CrossRef] 
[55] Essmann U, Perera L, Berkowitz ML. The origin of the hydration interaction of lipid bilayers from MD simulation of dipalmitoylphosphatidylcholine membranes in gel and liquid crystalline phases. Langmuir. 1995; 11(11): 4519-4531. [CrossRef]

[56] Bussi G, Donadio D, Parrinello M. Canonical sampling through velocity rescaling. J Chem Phys. 2007; 126(1): 014101014107. [CrossRef]

[57] Parrinello M, Rahman A. Polymorphic transitions in single crystals: A new molecular dynamics method. J Appl Phys. 1981; 52(12): 7182-7190. [CrossRef]

[58] Hess B, Bekker H, Berendsen HJ, Fraaije JG. LINCS: a linear constraint solver for molecular simulations. J Comput Chem. 1997; 18(12): 1463-1472. [CrossRef]

[59] Humphrey W, Dalke A, Schulten K. VMD: Visual molecular dynamics. J Mol Graph Model. 1996; 14(1): 33-38. [CrossRef]

[60] DeLano W. The PyMOL Molecular Graphics System; DeLano Scientific: San Carlos, CA, 2002. 2009.

[61] Kumari R, Kumar R, Lynn A. g_mmpbsa- A GROMACS Tool for High-Throughput MM-PBSA Calculations. J Chem Inf Model. 2014; 54(7): 1951-1962. [CrossRef]

[62] Hosseini Y, Mollica A, Mirzaie S. Structure-based virtual screening efforts against HIV-1 reverse transcriptase to introduce the new potent non-nucleoside reverse transcriptase inhibitor. J Mol Struct. 2016; 1125: 592-600. [CrossRef]

[63] Mollica A, Mirzaie S, Costante R, Carradori S, Macedonio G, Stefanucci A, Dvoracsko S, Novellino E. Exploring the biological consequences of conformational changes in aspartame models containing constrained analogues of phenylalanine. J Enzyme Inhib Med Chem. 2016; 31(6): 953-963. [CrossRef]

[64] Becke AD. Density-functional thermochemistry. III. The role of exact exchange. J Chem Phys. 1993; 98(7): 5648-5652. [CrossRef]

[65] Lee C, Yang W, Parr RG. Development of the Colle-Salvetti correlation-energy formula into a functional of the electron density. Phys Rev B. 1988; 37(2): 785-789. [CrossRef]

This is an open access article which is publicly available on our journal's website under Institutional Repository at http://dspace.marmara.edu.tr. 